
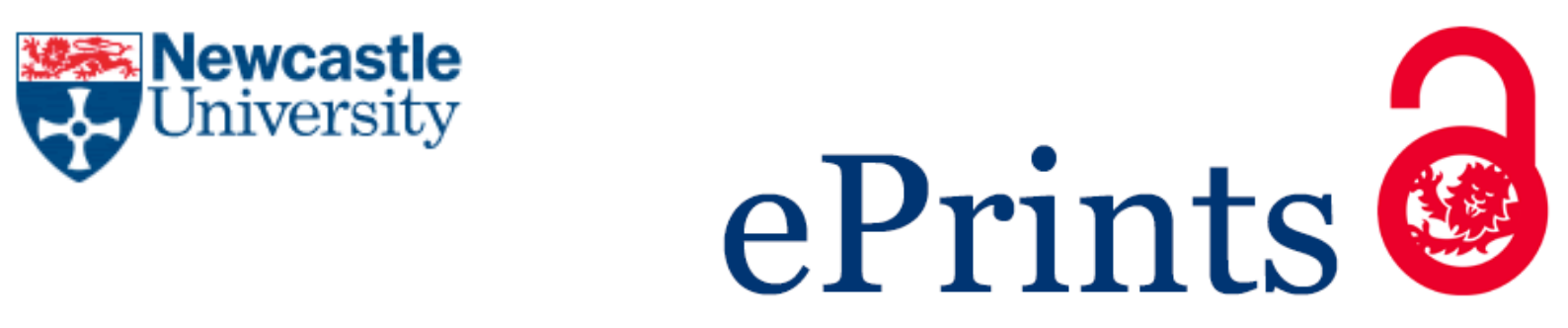

Walton A. (2014)

Global Democracy in a Society of Peoples.

Critical Review of International Social and Political Philosophy

DOI: 10.1080/13698230.2014.881099

\title{
Copyright:
}

This is an Accepted Manuscript of an article published by Taylor \& Francis Group in Critical Review of International Social and Political Philosophy on 03/02/2014, available online:

http://www.tandfonline.com/10.1080/13698230.2014.881099

Date deposited:

$03 / 03 / 2014$

Embargo release date:

03 September 2015

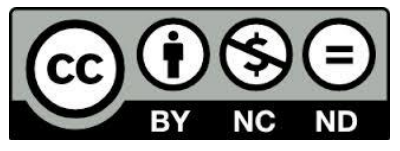

This work is licensed under a

Creative Commons Attribution-NonCommercial-NoDerivatives 4.0 International licence 


\section{Global Democracy in a Society of Peoples}

Abstract: This paper explores the political structures suitable for the realisation of Rawls' Law of Peoples. In particular, it explores whether Rawls' principles and fundamental foundations recommend establishing global institutions and, if so, whether, and in what sense, these institutions should be democratic. It is often suggested, either implicitly or explicitly, that The Law of Peoples would operate through the bilateral and multilateral interactions of, ideally-conceived, nationstates. This paper argues, on the contrary, that it would advise a series of democratic global institutions. The case is developed with respect to the idea of a global institution with the remit of regulating international trade and applied, in the contemporary context, to the World Trade Organisation.

Keywords: Global democracy; Rawls; The Law of Peoples; World Trade, Organisation

\section{INTRODUCTION}

In The Law of Peoples, Rawls envisages a world of territorially divided groups - 'peoples' which 'have their own internal governments', arguing that the demands of global morality apply to their 'mutual relations' (Rawls, 1999a, p. 3). This position has been subjected to various challenges. Some have argued that adopting a more complex, multi-layered system of political structures would be more desirable (cf. Pogge, 1994, pp. 85-118; Caney, 2005, pp. 148-188). Such proposals often retain a place for the state, but argue for diffusing sovereignty across different levels of governance, although some have advocated some form of world government (cf. Cabrera, 2004). Another line of criticism has focused on Rawls' commentary about the place of democracy in his vision of global justice. Some have argued that the aforementioned picture of multi-layered governance should include substantive components of democracy both across and beyond borders (cf. Held, 1995). Others have been critical of Rawls' ideas on democracy within the society of peoples, most significantly in his accrediting 'decent hierarchical peoples' with equal standing in this society (cf. Tan, 2006).

Despite this attention, it is interesting to note that there has been relatively little examination of precisely what political structures are involved in Rawls' society of peoples. It is common to understand it as involving only nation-states (of some form) interacting bilaterally or multílaterally with one another (cf. Pogge, 2006). It is undeniable that a society of peoples does, indeed, involve this feature. But Rawls explicitly discusses a considerable amount more. He envlsages a society of peoples also involving a 'law...governing the basic structure of the relations between peoples' (Rawls, 1999a, p. 33). It is thought that peoples 'should establish new institutions and practices to serve as a kind of confederative centre [sic]' (Rawls, 1999a, p. 93) and that there will be 'principles for forming and regulating federations (associations) of peoples... and other cooperative institutions' (Rawls, 1999a, p. 38). Rawls suggests that we should imagine analogues to the United Nations (Rawls, 1999a, p. 36, p. 42, \& p. 93), the International Monetary Fund (Rawls, 1999a, p. 84), the World Bank (Rawls, 1999a, p. 42 fn. 51), and the General Agreement on Tariffs and Trade (Rawls, 1999a, p. $42 \mathrm{fn} .51)$. These institutions may, on certain issues, 'have the authority to express for the society of well-ordered peoples their condemnation of unjust domestic institutions in other countries' (Rawls, 1999a, p. 36) and there will be guidelines 'for specifying various duties and obligations' within them (Rawls, 1999a, p. 86). It is possible to read these statements as suggesting nothing more than a variety of forums in which peoples negotiate. Yet, it also seems possible to read them as suggesting somewhat greater substance to global political affairs than mere inter-state relations. Which is the more plausible reading seems something 
that can be settled only if we explore more deeply what Rawls had in mind with these comments, and, indeed, what is the most defensible conception of a society of peoples.

In this paper I hope to provide impetus for such exploration by considering two lines of investigation. I will examine, first, the political structures suitable for society of peoples and, second, the question of whether any common centres and global institutions within this model should be democratically structured in some way. ${ }^{1}$

The merits of exploring these issues should be obvious. Doing so should provide us with a more complete picture of the model of global justice proposed by Rawls. Developing such a picture is useful of its own accord and for determining the strength of challenges to it. There are also clear practical merits. Although our world, undoubtedly, far from resembles the conception of the world proposed in The Law of Peoples, the commentary on/global institutions mentioned above has clear resonance with our contemporary global political landscape. By exploring the dimensions and merits of Rawls' view, we can also generate ideas about how these institutions should be structured in an ideal world and developed towards that goal.

The paper proceeds as follows. It begins by providing more detail on how a society of peoples might be conceived and defends the idea that it should include various global institutional structures. It, then, outlines and defends the claim that these institutions should exhibit, at least, two democratic features: (i) equal political/power, manifest, in part, through (ii) an aggregative voting system. The argument is brought into focus further by considering the application of the ideas to one existing global institution - the World Trade Organisation (WTO). Finally, the arguments are refined by engaging them with other literature on global democracy and WTO appraisal.

\section{THE LAW OF PEOPLES}

It is useful to begin by constructing a picture of Rawls' society of peoples. Such a picture can be developed by outlining of its core moral concerns and asking what political structures seem appropriate for upholding these concerns.

\section{Rawlsian global justice}

To conceptualise demands of justice, Rawlsian theory begins with an original position. ${ }^{2}$ The original position is a hypothetical choice scenario designed to issue fair terms of social cooperation between relevant parties. To use the device, three issues must be clarified. First, it must be determined which parties are relevant to a particular case. Second, we must specify the interests of these parties. We must ask: what do parties hope to gain in the agreement and what do they hope to avoid? Third, we need to stipulate the conditions of the "veil of ignorance'. The veil of ignorance deprives parties of knowledge of certain information in their decision-making in order to ensure they are not situated to bias principles towards certain features of their scenario. We must specify which features are unknown.

At the global level, Rawls asserts that the relevant parties are representatives of 'peoples', and, initially, only 'liberal peoples'. Liberal peoples are territorial entities with geographical borders marking their separation from other peoples (Rawls, 1999a, pp. 38-29). But they are principally defined by three features. They are thought to have a reasonably just internal structure, some sense of common sentiment between citizens (such as the bonds of

\footnotetext{
${ }^{1}$ Clearly, other lines of investigation are required in order to form a full picture of a society of peoples and how to realise it, but give the focus of common commentary on the idea mentioned in the opening paragraph, these two avenues seem a reasonable place to begin.

2 The following presents a summary of the original position suitable for the purposes of the paper drawn from across Rawls' work (Rawls, 1999a, pp. 30-35; Rawls, 1999b, pp. 10-19 \& pp. 106-168).
} 
nationality), and a 'moral nature', which implies they are willing to pursue their interests within fair terms of cooperation (Rawls, 1999a, pp. 23-25).

Such peoples are thought to have three central interests:

(i) They are concerned to protect their territory, political independence, and culture (Rawls, 1999a, p. 29 \& p. 34).

(ii) They wish to ensure the security, safety, and welfare of their citizens (Rawls, 1999a, p. 29 \& p. 34).

(iii)They desire proper self-respect of themselves as a people, involving 'receiving from other peoples a proper respect and recognition of their equality' (Rawls, 1999a, pp. 34$35)$.

Alongside knowing these interests, peoples in the original position 'know that reasonably favourable [sic] conditions obtain that make constitutional democracy possible') (Rawls, 1999a, p. 33). Yet, in accordance with the aims of the original position structure, they are deprived of knowledge of matters that may lead them to bias principles of cooperation in certain ways. They do not know, for example, 'the size of the territory, or the population, or the relative strength of the people...they represent' (Rawls, 1999a, p. 32) or 'the extent of their natural resources, or the level of their economic development' (Rawls, 1999a, p. 33).

Thus situated, parties in the original position select principles of global justice. Rather than recount the principles Rawls argues they would select, ${ }^{3}$ it is most useful for the purposes here to identify four central components of these principles. First, we observe a commitment to some notion of sovereign dominion insofar as peoples agree to respect one another's freedom and independence and, accordingly, a duty of non-intervention (Rawls, 1999a, p. 37). It is necessary to meet certain criteria to qualify for these privileges: a people must not be aggressive towards other peoples and it must respect the human rights of its citizens. ${ }^{4}$ But to the extent that a society meets these criteria, it becomes a moral requirement that it is treated, within these limits, as having sovereign mandate. Liberal peoples meet these criteria (Rawls, 1999a, pp. 25-27), as do 'decent hierarchical societies' even though they are not liberal (primarily insofar as they do not uphold equal rights to political participation and other basic liberties) (Rawls, 1999a, pp. 62-70\&pp. 83-84).

Second, peoples entitled to this privilege are entitled to be viewed as equals. That such respect is owed between liberal societies follows straightforwardly from their third interest noted above - their desire for proper self-respect, which depends, in part, on receiving proper respect and recognition of their equality from others. Rawls also extends this respect to decent hierarchical societies (Rawls, 1999a, pp. 84-85). In essence, it would seem that since decentpeoples meet the criteria to be admitted to the society of peoples, they too should be ascribed and treated as having an interest in self-respect and, accordingly, as entitled to be recognised as equals.

The third and fourth features concern how The Law of Peoples considers responding to peoples acting in ways which mean they do not fulfil the criteria of being a liberal or decent society. Here, Rawls argues that liberal and decent peoples are set a 'long-term aim...to bring all societies to honour [sic] the Law of Peoples and to become full members in good standing of the society of well-ordered peoples' (Rawls, 1999a, p. 93). This aim unfolds in discussion of two different cases. On the one hand, there is the issue of 'outlaw states', which are outwardly aggressive and do not respect the human rights of their citizens (Rawls, 1999a, p. 90 \& p. 81 respectively). Liberal and decent societies are encouraged to press for securing human rights in such states, which they may pursue through political or economic pressure or,

\footnotetext{
${ }^{3}$ The list can be found in Rawls (1999a, p. 37).

${ }^{4}$ Rawls' specification of human rights can be found in Rawls (1999a, p. 65).
} 
if necessary, through sanctions or intervention (Rawls, 1999a, p. 93). On the other hand is the case of 'burdened societies', which are failing to establish just or decent institutions because they 'lack the political and cultural traditions, the human capital and know-how, and, often, the material and technological resources' (Rawls, 1999a, p. 106). In these cases, liberal and decent societies have a 'duty of assistance', which requires that they provide aid or political inspiration (Rawls, 1999a, pp. 105-106).

Based on this, non-exhaustive, overview, Rawls can be thought to endorse the following demands of justice for a society of peoples:

1) Sovereign dominion for liberal and decent peoples.

2) Equal respect between liberal and decent peoples.

3) Promotion and protection of human rights where they are violated.

4) Promotion of just domestic institutions where they are absent.

As the description above suggests, these requirements entail various rights and duties. 1 seems to involve both a right (of sovereignty) and a duty (of non-intervention). 4, meanwhile, seems primarily to place duties on liberal and decent peoples, whilst being something similar to a right 'burdened societies' can claim. But the crucial point at this stage is that Rawlsian global justice does set forth a range of requirements that entail various rights and duties, all of which must be upheld in his society of peoples. It, thus, seems pertinent to ask: what political structures would be suitable for upholding these demands?

\section{A 'society' of peoples}

As noted above, it is often suggested, either explicitly or implicitly, that Rawlsian global justice operates in world comprising only peoples. ${ }^{5}$ Of course, peoples clearly are an important component of the world order prescribed by Rawls. However, it also seems clear that they are not the only component Rawls advocates, nor should they be so.

Rawls makes a number of comments on the further components of his conception of the global political order. Importantly, it is thought to include a number of global institutions. One of these serves a primarily political function. Some analogue of the United Nations, it is argued, would 'serve as a kind of confederative centre [sic] and public forum for [peoples'] common opinion and policy toward non-well-ordered regimes' (Rawls, 1999a, p. 93). The others mentioned are largely economic in some sense. An International Monetary Fund is to provide assistance to regimes which seek help developing more liberal institutions (Rawls, 1999a, pp. 84-85). Meanwhile, analogues of the World Bank and WTO are intended to enable peaceful forums for peoples to agree terms of cooperation (Rawls, 1999a, pp. 42-43). As Beitz writes, the institutional structure of the Society of Peoples' seems to involve 'a network of cooperative organizations concerned with matters of security, finance, and trade' (Beitz, 2000, p. 673).

It could be suggested that this system remains merely a set of sites for peoples to interact. I am unconvinced by this thought. Rawls suggests that there is a system of 'international law' that monitors the domains of war and sovereignty (Rawls, 1999a, p. 27). It would be strange to think that a system of international law is embodied by only state tête-àtêtes. Rawls also seems to suggest some more centralised aspect when he comments that it is through the analogue of the UN that peoples address outlaw states and that, accordingly, this institution will 'have the authority to express for the society of well-ordered people their condemnation of unjust domestic institutions in other countries' (Rawls, 1999a, p. 36). My point, though, is not that these institutions must have an independent life. The point is that

\footnotetext{
${ }^{5}$ This understanding is explicit in Pogge (2006), but it also seems implicitly present in Caney (2005, pp. 10-13).
} 
there is some form a systematised coordination at the global level. There will be, Rawls suggest, 'principles for forming and regulating federations (associations) of peoples' (Rawls, 1999a, p. 36) and 'guidelines...for specifying various duties and obligations' (Rawls, 1999a, p. 86). There is, in other words, a 'public system of rules'. 6 There is some form of global institutional setting which specifies, either of its own accord or through agreement between peoples, 'certain forms of action as permissible, others as forbidden' and provides for 'certain penalties and defences, and so on, when violations occur' (Rawls, 1999b, p. 55). There is, in short, not only a set of peoples, but a 'society' of peoples.

That, at any rate, is how I read the description that Rawls offers. Perhaps more importantly, it also encapsulates what, I think, offers the most plausible understanding of how a society of peoples should function. In the previous subsection, I suggested that Rawls' conception of global justice offers peoples, at least, four requirements which generate various rights and duties. The obvious rationale for conceptualising a society of peoples as a global institutional framework involving a public system of rules is that such a system will be valuable in terms of upholding these demands. Two points seem apposite.

The first concerns conditions conducive to compliance. It has been a common theme of domestic political thought that an important justification for the state is the value of a mechanism for ensuring that individuals comply with their duties of justice. Some suggest that its enforcement capacity is crucial here. ${ }^{7}$ Another position is that they help overcome hurdles presented by collective action problems. They can reduce the epistemic difficulties which face individual actors and provide assurance that others are complying. Such arguments are regularly made in defence of global political structures monitoring and overseeing the actions of states (cf. McGrew, 2002, p. 272; Caney, 2005, pp. 159-160), and it is easy to see why, especially in terms of the commitments Rawls' mentions above. It has proven extremely difficult to ensure nation-states observe the rights and duties surrounding non-intervention in the absence of a more developed global political system (cf. Pogge, 1994, p. 103). Similarly, on the issues of human rights protection and aid to burdened societies, the inability of states acting independently to meet the UN demand that they give $0.7 \%$ of their GDP to such causes is highly telling (UN, 2006).

Second, there is a justification from impartiality. The central idea here was expounded by Locke (1993 [1698], pp. 157-163). It is that individual actors are prone to judge both rights and duties with a certain bias towards their own circumstances. A centralised forum for determining and monitoring rules can reduce this bias by acting as a detached, impartial arbiter or, if guided by popular will, by balancing individual biases against one another. They offer a scenario in which all private judgement of every particular member being excluded, the communitycomes to be umpire, by settled standing rules, indifferent, and the same to all parties' (Locke, 1993 [1698], pp. 157-158). The value of this feature of institutions to the execution of justice is obvious. Hoping that each party in the society of peoples respects the rights of others and conducts their duties, we should value a system that is able to check the tendencies towards bias of all involved, and it would seem that a system with some centralised aspect for determining and monitoring rules is valuable to this end. Locke's rationale provides the intuitive impetus for the idea, but, again, many examples, from agreements on climate change to the history of conflict, seem to demonstrate its validity.

In short, there seem both exegetical and normative reasons to believe that a society of peoples should not comprise only interactions between peoples. It should involve common forums in which ongoing patterns of behaviour and cooperation are discussed and systems of rules are developed, specifying which actions are permissible and impermissible and how derogations will be addressed. The setting for The Law of Peoples is a society of peoples.

\footnotetext{
${ }^{6}$ This term is taken from Rawls (1999b, p. 55).

${ }^{7}$ This argument is famously defended in Hobbes (1985 [1651]).
} 


\section{GLOBAL DEMOCRACY}

The crucial points that have hopefully been established thus far are twofold. First, Rawlsian global justice attributes an important set of rights and duties to peoples. Second, it seems plausible to think that these rights and duties will be upheld, in part, through a set of global institutions which will, somehow, determine and monitor relevant rules of conduct. These points seem to raise a related question: how will the relevant rules of conduct be established? In this section, I answer this question with the assertion that they should be determined democratically.

Specifically, I advance two claims. First, I argue that peoples should have equal opportunity for engagement in the process that determines the rules. Second, I argue for final decisions on the rules (or on a group to decide upon the rules) to be made by aggregative voting in some form.

\section{Political equality}

The first of my arguments primarily aims to defend a foundational idea of democracy: equal political power, understood here as equal opportunity to participate in decision-making processes. Various institutional arrangements could meet this demand. But its presence distinguishes a system as foundationally democratic, rather than being monarchic or autocratic, or, more pertinently, oligarchic or technocratic.

The argument I shall employ to defend this position concerns the importance of equal political power in conveying the equal respect owed to each member of a society. The argument emerges from commentary on the importance of democracy in Rawls' work on domestic justice. Here, Rawls places considerable emphasis on each individual's 'capacity to understand, to apply, and to act from the public conception of justice which characterises the fair terms of social cooperation' (Rav1s, 2005, p. 19). The idea of individuals having this 'sense of justice' has various dimensions. Of greatest import here is its role in the equal respect owed to each person. Cohen writes that in Rawlsian thought:

'Citizens regard one another as equals in matters of social and political justice...in that we have, to a sufficient degree, the capacity to understand principles of justice, to offer reasons to others in support of them, and to assess the basic institutions within which we live and that shape our aims and identity in light of those principles' (Cohen, 2003, p. 107),

In short, being viewed as having a capacity to develop and exercise one's sense of justice is integral to the ideal of moral equality between individuals.

This thought connects to the idea of involvement in decision-making processes as follows. Self-respect is regarded as an important good by the individuals in the original position because it is a fundamental precondition for all our other ends. Whether we enjoy self-respect is determined, in part, by how others view us and, in particular, whether we are seen by them as equal moral persons; whether, that is, 'we regard one another as having, inter alia, the capacity for a sense of justice' (Cohen, 2003, p. 109). A crucial demonstration that we are seen as capable of forming and living by a sense of justice is the granting of responsibility for making judgements and influencing policy on matters of rights and fair distribution. In Cohen's words, 'when others respect me as an equal, they confirm my sense of my own value', and 'they show that respect by acknowledging and protecting my right to bring my sense of justice to bear on public affairs' (Cohen, 2003, p. 109). Moreover, it seems important that it is equal political power that is granted. Rawls utilises the phrase 'the fair 
value of political liberty' to convey the idea that 'the worth of the political liberties to all citizens...must be approximately equal, or at least sufficiently equal in the sense that everyone has a fair opportunity...to influence the outcome of political decisions' (Rawls, 2005, p. 327). The rationale for this commitment can be observed by considering the implications of its counterpoint. Unequal opportunities for participation suggest that the input of some is more valuable than others and that we are not genuinely committed to treating each party equally as holding a sense of justice. So, it is through granting the opportunity to participate that the capacity to develop and exercise a sense of justice is acknowledged and it is in granting it equally that their equality is recognised.

Although there are obvious differences, a similar case can be made in relation to a society of peoples. It was noted above that peoples are thought to have a 'moral nature'. Rawls writes that 'like citizens in domestic society' they are 'both reasonable and rational', willing 'to cooperate on fair terms' and willing to 'honour [sic] these terms when assured that other peoples will do so as well' (Rawls, 1999a, p. 25). These descriptions seem grounds for thinking that peoples be held to have an understanding of fair terms of conduct that can be developed and honed, as having, in other words, a 'sense of justice'. At was also observed that one of the fundamental interests of peoples is the desire for proper self-respect and, consequently, the interest in 'receiving from other peoples a proper respect and recognition of their equality' (Rawls, 1999a, pp. 34-35). Given the parallels, it does not seem unreasonable to draw similar connections between these ideas to assert that peoples should be seen as equal, inter alia, as having the capacity for a sense of justice and the self-respect they can properly feel will derive, in part, from the equal recognition of this capacity.

If this understanding of peoples is maintained, a similar argument can be made for the importance of equal opportunity for involvement in decision-making. As in the case for individuals, it would seem that the granting of political power is the proper acknowledgement of a people's capacity to develop and exercise a sense of justice and the granting of this power equally is the proper recognition of equality between peoples with this capacity. It seems similarly plausible to think that if global public rules are formed in a manner that does not give each people an equal opportunity to influence the determination of these rules, we have not respected their equal standing as actors with a sense of justice. What would respect this equality is granting peoples the fair value of political liberty in global decision-making.

\section{Aggregative voting}

While the previous argument focused on a foundational idea of democracy, my second argument develops the position towards a particular institutional characteristic: a role in decision-making for some form of aggregative voting. Again, various models - issue-specific referenda or elected leaders, majority rule or proportional representation, and so on - may meet this requirement. Similarly, I do not mean to suggest aggregative voting is the only important element of a democracy. The argument's main focus is to demarcate my proposal from a certain alternative: final decision by, passive or active, consensus. Two arguments give reason to favour the aggregative voting option.

First, there are constraints set by the number of participants. ${ }^{8}$ Essentially, the split between aggregative voting and decision by consensus regards how many parties must agree to a proposal for it to be deemed approved. Consensus requires unanimity, whereas aggregative systems require something short of that, perhaps a majority or a super-majority or merely the best-placed candidate. One merit of the latter is that decisions can resort to aggregation of votes. To be sure, it is valuable to include, say, deliberation in forming the available options. But it is possible, at some juncture, to deem the time for deliberation at an

\footnotetext{
${ }^{8}$ The broad point that follows is reasonably known, but a short statement of it appears in Weale (2007, p. 158).
} 
end and for the decision to be made through parties inputting their preferences and calculating the numbers. Unanimity can rarely be achieved in this fashion. Typically it requires other methods. On the one hand, if we follow active consent - the requirement that all parties expressly agree - negotiations and discussion can take place with the aim of formulating an agreement that suits all parties. But this procedure requires considerable, often impractical, time and resources when the numbers involved are anything other than very small. On the other hand, negotiation can proceed via passive consent - when no present party dissents. This process can be more practical, but only with an alternative price. To wit, if negotiations proceed without the inclusion of various parties. The relevance and significance of this dilemma depends somewhat on context. Yet even at the general level one can see how these problems arise when numbers reach even modest levels, such as $>50$ participants, in environments where difficult decisions need to be made regularly. And I suspect that Rawls' society of peoples meets these conditions. Even restricting the count to liberal and decent peoples, it seems likely that a Rawlsian global decision-making will involve numbers of this kind and it is hard to believe that there will be a small amount to decide given the divisiveness of topics like intervention, human rights protection, and aid. In such circumstances, there seems some reason to think that an aggregative voting system is a more viable way to realise equal political power than consensus-building.

Second, there is an important point about the relation between decision-making systems and the likelihood of certain outcomes. The concern is that realising progressive political outcomes, such as those which involve duties upon actørs that can bear the cost of helping protect human rights or providing aid, is more viable in a decision-making system that better opens the possibility of some parties being made worse-off. An aggregative system allows for the possibility that those who would rather not have further duties bestowed on them can be outvoted. It is much less clear how accessible this possibility should be deemed under a unanimity requirement. The difficulty is captured by Pettit:

'If the common interest is to be advanced...the decision-making procedure has to allow for some people to be treated less well than others. And a vetoing scheme would hardly fit the bill, since it would enable those from every quarter to rule out anything that damaged them' (Pettit, 1999, p. 179).

Of course, a veto also gives power for those to whom duties are owed to block decisions. But this power can serve only to maintain the status quo. It is unable to force progressive steps if another actor dissents. The relevance of this issue is also partly an empirical matter - it turns on how actors respond to different systems - and we must remember that Rawlsian peoples are motivated by a sense of justice. But we do have evidence to affirm the comparative merit of a voting procedure that can be drawn from existing supranational governance literature. It has been noted, for example, that within the European Union (EU) the prospect of voting 'is like the sword of Damocles hanging over the negotiating table', pushing even powerful members to respond more adequately to the interests of weaker parties to ensure requisite support (Bal, 2004, pp. 129-130). And although Rawlsian peoples may not mirror real world actors, we must be aware of both the tendency towards bias and apprehension about the choices of others and the fact that such peoples do retain components of self-interest in their actions. Thus, even in a world of largely reasonable actors, there seems value to a mechanism that can check these tendencies and allows progressive steps be made more simply.

\section{An initial sketch}

Now, even a minimalist understanding of democracy involves more than has been asserted above and many details have not been considered. But I take it that what has been argued 
gives some rationale for the global institutions in a society of peoples to be democratic in, at least, the senses suggested. In a system that has a set of public rules for coordinating interaction and upholding the rights and duties of a society of peoples, the demand for equality suggests peoples should have an equal platform for participation in determining those rules. Practicality gives some reason for this equal political power to be manifest through aggregative voting, as does the interest in the realisation of a progressive system that can exact the kinds of rights and duties Rawlsian global justice requires.

\section{DEMOCRACY AT THE WTO}

In order to make the above arguments more vivid and consider some of their implications, it seems useful to explore an instance of their application. Both the merits of the argunents and how they can be used to consider reform of our existing global architecture can be brought forth by reflecting on the case of the WTO. As noted above, Rawls conceptualises a place for an institution similar to the WTO. Rawls' suggestion seems to be that its purpose would be primarily to help establish appropriate rules for global trade. But it does-not seem incoherent to think that it could also have some role in assisting the promotion and protection of human rights or just institutions if these goals could usefully be funnelled through the structures of the global economy. It, thus, seems a reasonable case for testing the appropriate format for institutions tasked with upholding Rawlsian global justice.

The dimensions of WTO decision-making are roughly as follows. It is a one-memberone-vote organisation with an arrangement for various forms of majoritarian decisions. However, the institution does not use these procedures. Agreements are reached by consensus-building. They are formed by a group of 'interested' parties convening - in, socalled, 'Green Rooms' - to discuss the terms of trade in some particular area and a decision is deemed to have been reached when no present party dissents (Narlikar, 2002; Ehlermann \& Ehring, 2005, pp. 54-56).

There are three pertinent problems with this system. First, it does not provide all parties with equal opportunity to participate. The passive consensus model has the problem of being a presence-dependent decision procedure. If a party is not present, agreements are formed without their contribution, a difficulty that has confronted countries unable to afford permanent representation in Geneva or that cannot send large delegations or afford specialists to ensure they attend all discussions relevant to their interests (Narlikar, 2002, p. 175). Moreover, even when in attendance, less powerful states often experience a disadvantage compared to states that have greater resources to prepare their negotiation platforms and techniques and which such states often use to induce agreement. What follows from these experiences, often, is a feeling that they are not treated as equal partners in negotiation (Narlikar, 2002, pp. 175-176; Jawara \& Kwa, 2003).

Second, there is evidence of the dilemma between capacity constraints and inclusion. The consensus-building model worked reasonably when there were far fewer states involved, but now that WTO numbers and the quantity of issues on the agenda are higher, the viability of reaching an inclusionary consensus is much reduced (Schott \& Watal, 2000; Ehlermann \& Ehring, 2005, p. 68). Larger-scale negotiations have been extremely protracted and often inconclusive while the areas in which progress has been made are cases where Green Room discussions proceeded with a group of countries far short of the number that have a genuine interest in the area of discussion (Schott \& Watal, 2000; Keohane \& Nye, 2000, pp. 7-8).

Third, the actions of some states in consensus-oriented negotiation have served to prevent more progressive agreements being reached. For example, in negotiations surrounding the Trade Related Aspects of Intellectual Property Rights and public health which concerned how the former would impact the (right to) health, and, indeed, life, of many individuals - 'consensus could not be reached because one single Member felt unable to 
abandon its resistance against the proposed draft waiver' (Ehlermann \& Ehring, 2005, p. 64). Similarly, 'after launching the Tokyo and Uruguay rounds, powerful countries often blocked a consensus to advance initiatives by weak countries when they were introduced for formal action in the relevant negotiating committee' (Steinberg, 2002, p. 355). Various other examples can also be given in support of this point (cf. Steinberg, 2002, pp. 345-349; Ehlermann \& Ehring, 2005, pp. 64-68).

In contrast, there seems some reason to believe that the alternative structures I proposed above would combat these problems. The idea of the fair value of political liberty would seem to imply equalising the opportunity for countries to have input into agreement forming at the institution, perhaps by providing resources to bolster the delegation size and capacities of developing countries (Narlikar, 2002, p. 180). Developing such provision is already underway in the WTO's recent efforts on 'building trade capacity' (WTO, 2013) and furthering this programme would go some distance to removing the inegalitarian nature of the decision-making processes and removing the source of feelings of unequal respect

Final decisions by aggregative vote could be implemented in various ways. One possibility is that existing protocol for decision by (qualified) majority vote could be utilised more regularly (Ehlermann \& Ehring, 2005, pp. 71-72). An alternative suggestion is the formation of a steering committee that would attempt to formulate agreements on behalf of member states (Schott \& Watal, 2000). Such a committee could be elected via some system of representation. Either of these models would be likely to improve matters in the WTO in two respects. They would offer practical ways to ensure equal political control over decisions despite large numbers of participants and issues. In addition, the shadow of a vote would provide greater incentives to reach agreements that adyanced the rights of developing countries and their citizens (Ehlermann \& Ehring, 2005, pp. 72-73) and, in the final analysis, a means of forcing such decisions through that is problematic under the consensus system. ${ }^{9}$

There are clearly other reforms that would be valuable at the WTO. As I noted in the previous section, I do not mean to argue that incorporating an aggregative vote would be all that an interest in democratic values or WTO legitimacy would involve. Some prominent suggestions in literature are that crucial reform should focus on improving transparency, allowing publics to be better informed and better situated to hold their representatives to account (Keohane \& Nye, 2000, p. 12) and that we should increase involvement of civil society groups, perhaps to aid the cause of transparency or because it can improve deliberations or cross-learning (Slaughter, 2004, p. 162; Buchanan \& Keohane, 2006, p. 430). I see my proposals as complementing these ideas. Increased transparency, for example, would aid equal respect and, conversely, moving negotiations away from closed-door Green Rooms towards voting structures would increase the pressure on governments to make their arguments clearer and more accessible to a wider audience.

It is true that some of those who advocate these reforms juxtapose them with greater democratisation (cf. Keohane et al., 2009, pp. 9-18). However, their main focus here is to argue against greater public involvement on the grounds that it may allow special interest groups to obstruct progress on long-term public goods, such as freer trade. This position and its justification do not stand against the proposal I have made for greater equality between states and the manifestation of this equality through an aggregative vote. Indeed, as my earlier arguments suggest, there may, again, be reason to believe that the aggregative vote component accords with the motivations of such arguments on the grounds that it may be helpful for circumventing other factions which obstruct progressive agreements.

\footnotetext{
${ }^{9}$ It is perhaps worth noting here that if there is fear such structures may also leave open the possibility that powerful states organise a majority to force regressive agreements, we could supplement the voting system with some continued form of veto power for developing countries, as suggested in by Margaret Moore (2006, pp. 37$38)$.
} 
In short, I contend that the WTO case supports both the contentions of the previous section. Of course, we must remain careful about what we infer from real world politics about a society of peoples. There would clearly be other differences between the two that could alter the realities and value of various institutional features. But it is not unreasonable to think that our experience of global political structures contributes some information on how such institutions will most appropriately operate. The case of the WTO, I submit, is both an example of the problems with a lack of democracy between peoples and evidence that such institutions, to be most valuable in terms of pursuing Rawlsian global justice, should work towards ensuring equal opportunities for participation amongst their members and should utilise recourse to aggregative voting to make final decisions on the rules.

\section{REFINING}

The arguments above have, hopefully, set forth a positive statement on the value of global democracy in a society of peoples and begun to sketch how the idea should be conceived. I do not have space to address all possible objections and details here. But I will use the remaining space to address some of the most obvious challenges to it and use these questions to refine certain elements. In doing so, my main focus is the more abstract analysis of the society of peoples, but I will continue to engage the ideas with practice at the WTO in order to draw relevant evidence and consider the application of the ideas.

\section{Sovereign equality}

The first worry is that global democracy would clash with the sovereign equality of peoples. It was noted above that peoples have an interest in securing their political and cultural independence. It might be thought that deference to a global institution in which binding decisions are made would be in tension with these interests. There may also be concern that such institutions would limit the space for national democratic decisions. Both worries are cited as reasons against moving away from the consensus system at the WTO (cf. Steinberg, 2002, p. 361; Warwick Commission, 2007, p. 29) and it might be thought that they would readily exist among Rawlsian peoples.

I have three responses. First, whilst sovereignty of some form is an important value in Rawls' Law of Peoples, it should not be understood in the traditional sense. As noted above, sovereignty here is understood more as a privilege than a right, limited to some extent by the demands of global justice. It is quite proper, Rawls writes, that 'international law...tends to limit a state's right to wage war...and...to restrict a state's right to internal sovereignty' (Rawls, 1999a, p. 27). This restriction on sovereignty, Rawls thinks, is quite compatible with the interest of peoples. Second, it is worth noting that the extent to which a people's independence is preserved is not merely a matter of formalised institutions. It is, in part, an empirical question regarding what structures best preserve independence, and it may be that collaborating within certain supra-national organisations is what is best. Pettit argues along these lines that, given the threat offered by, for example, corporations or financial institutions, it is plausible to believe that cooperation within global institutions is the best mechanism for securing sovereignty in a globalised world (Pettit, 2010, pp. 70-94). Finally, we can limit the possible tension between global democracy and sovereignty by organising our political system to reflect these concerns somewhat. For example, we can adopt a fairly strict principle of subsidiarity, similar to the EU system, regarding which issues are addressed at the global level and we can allow peoples considerable flexibility in the methods of implementation of many requirements. Together, these comments hopefully offer enough to suggest that some form federalist or confederalist governance structure should be compatible with a concern for the kind of sovereignty entailed in a society of peoples. Rawls, at least, seemed to think they 
would be compatible (Rawls, 1999a, p. 93 \& p. 111). At any rate, they should be sufficient to dispel the thought that the two are necessarily in tension.

\section{People and peoples}

A second concern regards the focus in my arguments on peoples. There are two angles from which this focus may be deemed troubling. It may be suggested that it neglects the fundamental concern for the existence of democratic relations between individuals worldwide (cf. Held, 1995). It may also be wondered how my position addresses the non-ideal aspects of Rawlsian theory. Not all peoples will not be 'well-ordered', but both my arguments on global democracy and my application to the WTO rather bypassed this issue. It might be-wondered how my proposals will address these groups. ${ }^{10}$

In response to the first worry, I make two points. First, nothing I have argued would negate the possibility of global citizen parliament(s). Indeed, one value of such an arrangement might be to realise a useful balance of powers between individuals and national governments, giving individuals some avenue for holding their representatives to account through post-national courts, for example. I do not think this idea contradicts my proposals. Nevertheless, it seems worth stressing, second, that we should not overstate the importance of directly involving individuals in global politics, at least from within the parameters that I have developed here. If the aim is to ensure individuals have some form of involvement in the structures that govern their lives, it should go some way to meeting this goal in my model to ensure that individuals have some control over their national representatives.

This response, however, leads us directly to the second concern raised above: how to address non-well-ordered peoples. On this issue, it is important to stress that the concern arises only within a non-ideal world. This seems important because whatever comment is offered on it, the objection cannot undermine the case for global democracy within the society of well-ordered peoples. It is important also because it directs us to consider the issue from the perspective of the general aim Rawls' sets for non-ideal circumstances: 'to bring all societies to honour [sic] the Law of Peoples and to become full members in good standing of the society of well-ordered peoples' (Rawls, 1999a, p. 93). It should be clear that how to achieve this aim is, in large part, an empirical matter. What it requires depends on what will effectively push all peoples to be well-ordered. From this perspective, it becomes plausible to think that including even non-well-ordered peoples within global democracy is an acceptable position. Rawls was distinctly keen on thinking that a strategy of incorporation and friendly pressure was a good approach, at least in a number of cases (cf. Rawls, 1999a, pp. 108-111). There is also some evidence to support this idea from the context of application discussed above. Under Article XXIV of the General Agreement on Tariffs and Trade, countries can voluntarily establish a General System of Preferences. ${ }^{11}$ These agreements establish a preferential terms of trade for developing countries, usually made conditional upon the latter meeting certain criteria, usually human rights obligations, including, at times, democratic standards. Of course, whether this strategy is optimal for improving human rights respect or democracy in less-well-ordered peoples is debatable. But there is enough evidence to suggest that there are a variety of mechanisms for addressing the worry over such states that operate within the institutional context. Thus, it does not seem unreasonable to propose that the ideas on global democracy detailed above might be suitably applied to an all-inclusive version of,

\footnotetext{
${ }^{10}$ Although the main focus here is the society of peoples, it is worth noting that the worry over non-democratic states is used as an argument against global democracy in some literature on the WTO (cf. Buchanan \& Keohane, 2006, p. 416).

${ }^{11}$ For details see Bartels (2005, pp. 463-487).
} 
say, the WTO provided that appropriate internal mechanisms are designed for moving towards a world in which it more accurately resembles a society of peoples.

A final variant of the above concerns is the claim that democracy is a problematic ideal in the global context because there is no reasonable way to apply the idea of onemember-one-vote. It is argued that one-individual-one-vote gives disproportionate weight to large countries, while one-country-one-vote gives disproportionate weight to small countries (Keohane \& Nye, 2000, p. 12; Kahler, 2004, p. 136). Such criticisms seem overly hasty, though. We often accept disproportionate weighting in domestic democracy - for example, in unequally sized regional groups electing the same number of representatives - when doing so helps improve the overall balance of interest representation or the likelihood good outcomes (Dworkin, 2000, pp. 200-204). Moreover, it does seem that various intermediary grounds could be considered, such as the model incorporated in The Lisbon Treaty (Article 16), which requires the support of $55 \%$ of member-states representing $65 \%$ of the population. The merit of such a system is that it ensures decisions balance the interests of large and small states, allowing neither to impose decisions too easily on others. Of course, our cholce of specific political structures must depend on various issues, but, again, hopefally these ideas are sufficient to show that global democracy is not necessarily in tension with allotting the appropriate place for persons or (different types of) peoples.

\section{Free and equal peoples}

A third issue for discussion regards Rawls' own views on democracy at the global level. Strictly, Rawls says nothing for or against the global institutions he advocates being democratic (Rawls, 1999a, pp. 42-43). But, as noted above, some commentators have thought Rawls did not place great value on democracy in the global realm. Accordingly, it might seem that he would have reasons to reject my arguments. Perhaps the most likely source of worry would focus on Rawls' claim that principles of justice should be founded on ideas common in the political culture of relevant actors (cf. Rawls, 2005, pp. 13-15). The difficulty this position may create for my argument is focused by Joshua Cohen's arguments on a human right to democracy (Cohen, 2006). The point is as follows. The value of democracy is, at least in part, a product of the idea that parties to a certain set of collective decisions should be seen as 'free and equal'. Following Rawls' thought about the foundations of justice, it is possible to mobilise this notion in favour of democracy in liberal societies, because in such societies there is some sense of shared belief in it. However, matters are more problematic when the scope of justice is expanded, since there are many societies in which it is not shared. If the demands of justice are supposed to supervene, in some way, on ideas affirmed in common culture, democracy cannot be deemed a moral demand in such contexts. Such a case can be made against a human right to democracy. It would seem possible that the same concern might apply to my arguments if the notion of 'free and equal' peoples is not shared across societies. ${ }^{12}$

My response to this objection is to deny both of its premises. First, it seems difficult to believe that any substantive notion of consensus can figure as a foundational element of theorising about justice. As Moellendorf writes: 'a theory of justice is supposed to include an account of what people are entitled to, not what many people believe people are entitled to' (Moellendorf, 2002, p. 13). The alternative, I think, is to ground arguments of justice on fundamental values, but if this move is made, the fact of disagreement between cultures cannot have any bearing on their validity. Second, we can also deny the claim that the idea of peoples as 'free and equal' is not shared across borders, at least in this case. In the theoretical

\footnotetext{
${ }^{12}$ It is worth noting that the idea of utilising voting within the WTO is rejected by the Warwick Commission for reasons along these lines (Warwick Commission, 2007, p.29).
} 
argument I offered, it was stipulated ex hypothesi that (qualifying) peoples view each other as free and equal, in this case as equals in holding a sense of justice. Moreover, there is some evidence that such beliefs have currency in practice even amongst a much wider range of states. Indeed, it was reference to the claims of many of those who might be thought to object to this value that made the case for improving WTO democracy so compelling. My sense, therefore, is that the concern simply does not have application in the context of discussion.

\section{Affinity}

The next objection to consider concerns affinity between parties comprising the demos. Democracy, it has been argued, requires some form of shared sentiment, such as nationality or common political culture, because this ensures the bonds between co-members are sufficient for those who lose elections or referenda to accept and abide by the will of the majority, The absence of such commonalities and solidarity at the global level, the argument continues, makes the idea of global democracy problematic (Kymlicka, 2001, pp. 226-277\& pp. 238240; Miller, 2010, pp. $145-146$ \& pp. 149-151). ${ }^{13}$

I have two responses. First, it is unclear how persuasive this criticism should be deemed in any conception of democracy. Ultimately, it is an empirical claim regarding the possibility of building sufficient affinity between parties to sustain democratic values. It seems intuitive to think that size and diversity will create problems in this regard. But the available empirical evidence contradicts this intuition. India formed a political system that is, at least, recognisably democratic amidst considerable diversity (Koenig-Archibugi, 2011, pp. 530-531). More generally, in the largest empirical study of this issue to date, Fish and Brooks find no evidence that fractionalisation, at leastalong linguristic, ethnic, or religious lines, has a negative impact on the prospects of democracy (Fish \& Brooks, 2004, pp. 156-166). Such research can be challenged and, anyway, it does not test hypotheses at the global level. But given that the available data suggests the issue of affinity is not as problematic as it intuitively may seem, there is more reason for optimism than pessimism.

Second, it should be noted that the question of affinity is not unique to democracy. It was argued above that a society of peoples requires some system of global public rules, asking a diverse array of actors to observe certain patterns of behaviour, including meeting the duties The Law of Peoples prescribes. It seems reasonably clear that the motivation to abide by such rules or norms -will require at least as much affinity as abiding by the decisions of global institutions. Both, ultimately, rely on a willingness to accept abiding by rules even if they are not in one's self-interest or are different to what one desires. Indeed, it seems plausible to think that bbserving these rules will be all the more acceptable to peoples if they know that the rules were devised through a fair process.

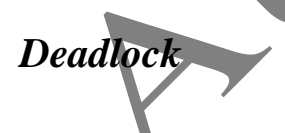

To bring the paper to a close, I wish to address one final concern that lies on the border between ideal theory and progress towards its realisation. The worry is that departures from consensus decision-making might be futile or counterproductive. It has been suggested that the WTO is under threat of collapse if changes of these kinds are considered, given the already-existing tendency of wealthier states to operate bilaterally or regionally when they do not reach the agreements they desire (Kahler, 2004, pp. 149-150; Warwick Commission, 2007, p. 29). It might similarly be thought that even Rawlsian peoples might be resistant to forgoing the possibility of veto power in such an organisation.

\footnotetext{
${ }^{13}$ Again, although my focus here is the society of peoples, it is worth noting that the same concern has been raised regarding the idea of greater democratisation of the WTO (cf. Keohane \& Nye, 2000, p. 11).
} 
It seems to deflect the immediate practical worry somewhat to highlight the following. Many global institutions already face difficulties with deadlock (cf. Narlikar, 2010a). The Doha Development Round has been on-hold for over a decade at this point and shows little sign of resolution. With this problem in the background, the WTO is already suffering from inertia and a tendency to form agreements outside its domain. Perhaps changes would lead to more of these problems in some areas, but resolve them in others. There is some reason to believe that aggregative voting procedures would actually enhance the ability of the WTO to circumvent certain quagmires caused by pluralism in consensus-based decision-making (cf. Narlikar, 2010b, pp. 722-723). Given these considerations, it is unclear how troubling worries over deadlock under alternative arrangements should be deemed.

My sense, therefore, is that the only enduring difficulty is that 'big powers' be resistant or will exit if they are subjected to rules they dislike. But this worry cannot be giyen too much recognition. One would hope that well-ordered Rawlsian peoples would not be so impervious to changes advancing the cause of justice and even if so, we seem to face the same kind of problem as the worry of states seceding from the union when the abolition of slavery was advocated or continued concerns that the wealthy will emigrate if $/$ we advocate higher taxes and more egalitarian distribution. Such worries matter, but only as reason to move strategically in how we promote and realise the agenda. They do not question the justice of it or, consequently, give any reason for it not to be followed. If global democracy is what a society of states requires of an institution like the WTO, it is this goal we should, somehow, pursue.

\section{Acknowledgements}

I owe thanks to an audiences at the University of Gallen's Department of Political Science Seminar Series and Department of Philosophy Seminar and at a seminar organised by the Transdemos research group at the University of Stockholm's for comments on an earlier draft of this paper, to two anonymous referees at Critical Review of International Social and Political Philosophy, and special thanks to Robert Jubb, Dominic Kelly, Bruno Leipold, and Andrew Williams for their helpful discussion of it.

\section{Reference List}

Bal, L.J., 2004. Member states operating in the EU Council of Ministers: inside impressions. In: P.W. Meerts \& F. Cede, eds. Negotiating European Union. Hampshire: Palgrave MacMillan, 127-142.

Bartels, L., 2005. The Appellate Body Report in European Communities - Conditions for the Granting of Tariff Preferences to Developing Countries and its Implications for Conditionality in GSP Programmes. In: T. Cottier et al., eds. Human Rights \& International Trade. Oxford: Oxford University Press, 463-487.

Beitz, C., 2000. Rawls' Law of Peoples. Ethics, 110 (4), 669-696.

Buchanan, A. \& Keohane, R.O., 2006. The Legitimacy of Global Governance Institutions. Ethics \& International Affairs, 40 (4), 405-437.

Cabrera, L., 2004. Political Theory of Global Justice: A Cosmopolitan Case for the World State. London: Routledge.

Caney, S., 2005. Justice Beyond Borders: A Global Political Theory. Oxford: Oxford University Press. 
Cohen, J., 2003. For a Democratic Society. In: S. Freeman, ed. The Cambridge Companion to Rawls. Cambridge: Cambridge University Press, 86-138.

- 2006. Is there a Human Right to Democracy? In: C. Synpowich, ed. The Egalitarian Conscience: Essays in Honour of G.A. Cohen. Oxford: Oxford University Press, 226248.

Dworkin, R., 2000. Sovereign Virtue: The Theory and Practice of Equality. Cambridge, Massachusetts: Harvard University Press.

Ehlermann, C.-D. \& Ehring, L., 2005. Decision-Making in the World Trade Organisation. Journal of International Economic Law, 8 (1), 51-75.

Fish, S. \& Brooks, R.S., 2004. Does Diversity Hurt Democracy? Journal of Democracy, 15 (1), 154-166.

Held, D., 1995. Democracy and the Global Order: From the Modern State to Cosmopolitan Governance. Cambridge: Polity.

Hobbes, T., 1985 [1651]. Leviathan. London: Penguin Classic.

Koenig-Archibugi, M., 2011. Is Global Democracy Possible? European Journal of International Relations, 17 (3), 519-542.

Jawara, F. \& Kwa, A., 2003. Behind the Scenes at the WTO:The Real World of International Trade Negotiations. New York: Zed Books.

Kahler, M., 2004. Defining Accountability Up: the GlobalEconomic Multilaterals. Government \& Opposition, 39 (2), 132-158

Keohane, R.O. \& Nye, J.S., 2000. Between Centralisation and Fragmentation: The Club Model of Multilateral Cooperation and Problems of Democratic Legitimacy. John F. Kennedy School of Government Working Paper, 01-004.

Keohane, R.O. et al., 2009. Democracy-Enhancing Multilateralism. International Organization, 63 (1), 1-31.

Kymlicka, W., 2001. Politics in the Vernacular: Nationalism, Multiculturalism, and Citizenship. Oxford: Oxford University Press.

Locke, J., 1993 [1698]. Two Treatises of Government. London: Dent.

McGrew, A., 2002. Liberal Internationalism: Between Realism and Cosmopolitanism'. In: D. Held \& A. McGrew, eds. Governing Globalization: Power, Authority and Global Governance. Cambridge: Polity, 267-289.

Moellendorf, D., 2002. Cosmopolitan Justice. Boulder, Colorado: Westview Press.

Miller, D, 2010. Against Global Democracy. In: K. Breen \& S. O’Neill, eds. After the Nation. Baskingstoke: Palgrave, 141-160.

Moore, M., 2006. Globalization and Democratization: Institutional Design for Global Institutions. Journal of Social Philosophy, 37 (1), pp. 21-43.

Narlikar, A., 2002. The Politics of Participation: Decision-Making Processes and Developing Countries in the World Trade Organisation. The Round Table, 364 (1), 171-185.

— ed. 2010a. Deadlocks in Multilateral Negotiations: Causes and Solutions. Cambridge: Cambridge University Press. 
2010b. New Powers in the Club: The Challenge of Global Trade Governance. International Affairs, 86 (3), 722-723.

Pettit, P., 1999. Republican Freedom and Contestatory Democracy. In: I. Shapiro \& C. Hacker-Cordón, eds. Democracy's Value. Cambridge: Cambridge University Press, 163-190.

2010. A Republican Law of Peoples. European Journal of Political Theory, 9 (1), 70 94.

Pogge, T., 1994. 'Cosmopolitanism and Sovereignty'. In: C. Brown, ed. Political Restructuring in Europe: Ethical Perspectives. London: Routledge, 85-118.

2006. 'Do Rawls's Two Theories of Justice Fit Together? In: R. Martin \& D.A. Reidy, eds. Rawls's Law of Peoples: A Realistic Utopia? Oxford: Basil Blackwell, 206-225.

Rawls, J., 1999a. The Law of Peoples. Cambridge, Massachusetts: Harvard University Press. 1999b. A Theory of Justice (Revised Edition). Cambridge, Mas\$achasetts: Harvard University Press.

2005. Political Liberalism (Expanded Edition). New York: Columbla University Press.

Schott, J.J., \& Watal, J., 2000. Decision Making in the WTO. International Economics Policy Briefs, No. 00-2.

Slaughter, A.-M., 2004. Disaggregated Sovereignty: Towards the Public Accountability of Global Government Networks. Government \& Opposition, 39 (2), 159-190.

Steinberg, R.H., 2002. In the Shadow of Law or Power? Consensus-Based Bargaining and Outcomes in the GATT/WTO. International Organization, 56 (2), 339-374.

Tan, K.-C., 2006. The Problem of Decent Peoples. In: R. Martin \& D. Reidy, eds. Rawls's Law of Peoples: a Realistic Ut bia? Malden: Blackwell, 76-94.

UN, 2006. The 0.7\% Target: An ip-depthlook. Available from: http://www.unmillenniumproject.org/press/07.htm [Accessed 13 ${ }^{\text {th }}$ March 2013].

Warwick Commission, 2007. The Multilateral Trade Regime: Which Way Forward?, Coventry: University of Warwick.

Weale, A., 2007. Democraøy. Hampshire: Palgrave MaxcMillan.

WTO, 2013. Building Trade Capacity. Available from http://www.wto.org/english/tratop_e/devel_e/build_tr_capa_e.htm [Accessed $18^{\text {th }}$ November 2013].

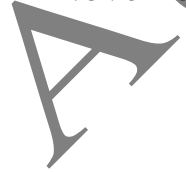

